\title{
19 \\ Politics in Wales since devolution
}

\author{
Diana Stirbu and Laura McAllister
}

\section{Introduction: the politics of territory and identity in Wales}

The history of modern Welsh politics is better represented by continuity, rather than dramatic or radical change. Its electoral history has been characterised by loyalty to a single party: first to the Liberals (between 1885 and 1918), then to the Labour Party for most of the 20th century.

There has been a tendency amongst scholars to overlook Wales. Consequently, distinctive aspects of the profile of the Welsh nation - notably its two languages, geography, demography, industrial and class structure and its politics - have been largely ignored outside Wales. This chapter provides an overview of recent developments in Welsh politics since the referendum on devolution in 1997 and the subsequent establishment of the National Assembly for Wales (Assembly) in 1999. In focusing on the key developments that have shaped Wales's new democracy, we examine the development of the Assembly as an institution, the evolution of the political parties in Wales and their adaptation to devolution, and also new representation and voting patterns that have emerged since devolution. Finally, this chapter sets out the significant developments in scholarship on these areas.

\section{The state of play: Welsh politics since devolution}

\section{Background: towards a Welsh Parliament}

The historically long-standing political relationships between Wales and England had dominated politics in Wales before devolution. Wales lacked the infrastructure of independent statehood that Scotland enjoyed, in terms of distinctive institutions such as education and legal systems. Wales's enduring distinctiveness depended instead on social, cultural and linguistic differences. The Wales Office was established only as late as 1964, whereas Scotland had its own measure of administrative devolution since 1885. Politically, Welsh exceptionalism had been emphasised by a strong left of centre, collectivist and trade unionist flavour for most of the previous 150 years. The context of successive Conservative governments at Westminster (1979-97), with Wales (unlike Scotland) never having elected a majority of 
Conservative MPs, raised the issue of an apparent democratic deficit (Wilson, 1994). This shaped the next stages of political discourse around greater autonomy and devolution. Labour, as the dominant party, had held an ambivalent position on devolution to Wales. In 1979, when the question of creating an Assembly was first put to the people in a referendum, most prominent Labour MPs (including the future Labour leader, Neil Kinnock) campaigned against it (Deacon, 2018). In the 1980s and 1990s, Scotland was deeply engaged in a cross-party national conversation over its constitutional future. In Wales, the 'Campaign for a Welsh Assembly', established in 1987 and rebranded as the 'Parliament for Wales Campaign' in 1993, achieved a fraction of the scale and reach of its Scottish counterpart (Rawlings, 1998).

Following the marginal endorsement of devolution in the 1997 referendum $^{1}$ and its establishment in 1999, the Assembly has transformed the focus of Welsh politics. Whilst its creation was predicated on the grounds of better government, closer to the people, devolution inevitably gave a greater profile to a distinctive new politics in Wales (Wyn Jones, 2001).

As the democratically elected body that represents the people of Wales, the Assembly, controls a budget of $\mathcal{E}_{18}$ billion (2019-20), makes laws for Wales and scrutinises the Welsh Government.

\section{The changing constitution of Wales: structures, powers, politics}

To understand contemporary developments in Welsh politics, we need to understand the devolution journey in Wales, which will demonstrate how different the current Assembly is to the institution established in 1999 in terms of legal status, powers, competencies and internal structure and operation.

In many ways, Wales has witnessed the most constitutional change of all the UK nations since the devolution programme was rolled out in 1999. At the time of writing (August 2019), the Assembly has powers to make laws in all matters that are not specifically reserved to the UK Parliament. Health, social care, transport, education, agriculture and economic development are some areas where the Assembly enjoys significant competence to legislate. General and specific reservations are listed in Schedules 7A and 7B of the Government of Wales Act 2006 (amended by the Wales Act 2017), notably around the constitution, defence, foreign affairs, etc. With the passage of legislation in 2014 and 2017, Wales gained significant tax raising (including land transaction tax and landfill disposal tax) as well as borrowing powers, meaning that from April 2019, the Welsh Government raises around 20 per cent of its budget.

The fact that the Assembly now, to all intents and purposes, resembles a proper parliament ${ }^{2}$ is relevant, as it was established initially as a corporate body, that is, as an institution that merged the administrative functions previously exercised by the Welsh Office (a UK Government department, a branch of executive power), with the representative functions of a directly elected political body, akin to a branch of legislative power. This odd hybrid was unlike almost all other legislative bodies in the world. The Assembly had no powers to legislate, merely to modify legislation passed by the Westminster Parliament. It was financed entirely through a block grant determined by the UK Treasury, in line with the population-based funding Barnett formula and had no tax varying or borrowing powers. It had no authority over its size, electoral system, or structure (Stirbu \& McAllister, 2018).

With limited legitimacy and few powers, the original Assembly was likened to a glorified local council, or a 'talking shop'. Nevertheless, the expectations surrounding the new institution far exceeded reality, especially given the serious constitutional shortcomings of the 
Assembly's original design. Expectations were that the new institution would promote a new and different, more inclusive politics (McAllister, 2000), which would in turn lead to greater accountability and more effective governance (Wyn Jones, 2001).

To some extent, some of these expectations of 'distinctiveness' from Westminster politics did materialise. The first Assembly broke records for levels of women's representation, not just in the UK but beyond, with 40 per cent women AMs elected in 1999. In 2003 the proportion of women AMs rose to 50 per cent and in 2006 to 52 per cent, whilst currently there are 47.7 per cent women AMs in office in the Assembly. Secondly, members in the Chamber addressed each other by their first names rather than 'Honourable Gentleman' or 'Honourable Lady', and the Assembly was committed to adhering to family-friendly working hours (Stirbu, 2010).

Wales' constitutional trajectory post devolution reflects the evolution of a new politics, punctuated by a series of necessary, deliberative consultations and reviews that sought to reach out to wider communities in Wales, including academia, local government, businesses, the charity sector and the general public (see Table 19.1 below). The main preoccupation of these exercises, whilst addressing the Assembly's constitutional design flaws, was to shape Wales' new democratic space. And with the prospect of enhanced powers for the Assembly, more tax and fiscal responsibilities, and more autonomy over internal affairs, the political space for contestation has become more attractive over the years. A brief timeline is provided here:

Labour's electoral dominance has continued after devolution in that the party has been in government in Wales since 1999. However, Labour has not had it all its own way and two other parties have been part of coalition arrangements or supported Labour minority governments in this time (the Liberal Democrats in the first Assembly term and with a government minister in the fifth Assembly, then a coalition with Plaid Cymru in the third Assembly and a 'confidence and supply' arrangement in the fifth Assembly). Secondly, given political and electoral dynamics in Wales (the difficulty of obtaining an overall majority in the Assembly due to the electoral system used and voting patterns), political parties have become more accustomed to different models of power-sharing and government, such as minority or coalition governments backed by conditional 'confidence and supply' support. Thirdly, it is noteworthy that some of the important constitutional deliberations and initiatives in Wales have happened in the context of coalition governments (either in Cardiff or in London): for example, the Richard Commission between 2002 and 2004 (under a Labour-Lib Dem coalition in Cardiff), the All Wales Convention (2008-9) appointed as part of the coalition agreement with Plaid Cymru in the third term, the Silk Commission appointed under the UK Conservative-Lib Dem coalition government etc.

\section{Political parties}

There are currently seven political parties that hold some elected office at the different levels of government in Wales: Welsh Labour, Welsh Conservatives, Plaid Cymru, Welsh Liberal Democrats, UKIP, the Wales Green Party and the Brexit Party. There are also independents at Assembly and local government level.

Devolution has brought about some important changes in the way the UK-wide political parties are organised and operate in Wales. The Welsh Labour and Welsh Conservatives, traditionally considered as regional branches of the two big UK parties (Bradbury, 2006), have had to shift significantly in the face of devolution, more so than the Lib Dems for instance, who operate a federal structure, or Plaid Cymru, who only operate in Wales. Nowadays, both Welsh Labour and the Welsh Conservatives have much more autonomy over policy formation, leadership structures, organisation and internal processes. 
Table 19.1 Political and constitutional developments timeline

\begin{tabular}{|c|c|c|}
\hline Interregnums & Political developments & Constitutional developments \\
\hline $\begin{array}{l}\text { Corporate body } \\
(1999-2007) \\
\text { Government of Wales } \\
\text { Act } 1998\end{array}$ & $\begin{array}{l}\text { Political congruence, with the Labour } \\
\text { party in power in Cardiff and London. } \\
\text { Vote of no confidence in the Assem- } \\
\text { bly's First Secretary Alun Michael in } \\
\text { January 2000, and the election of } \\
\text { a new First Secretary, Rhodri Morgan. } \\
\text { Coalition partnership between Labour } \\
\text { and the Lib Dems (Oct 2000-3). } \\
\text { Majority Labour government } \\
\text { (2003-7). } \\
\text { leuan Wyn Jones is elected as Plaid } \\
\text { Cymru's Assembly party leader in } \\
\text { Summer } 2001 \text {, a position from which } \\
\text { he resigns in 2003, only to stand for it } \\
\text { again and be reelected as party leader } \\
\text { in the same year. }\end{array}$ & $\begin{array}{l}\text { Richard Commission appointed by the } \\
\text { UK Government in } 2002 \text { to look at } \\
\text { powers and electoral arrangements of } \\
\text { the National Assembly. The Commis- } \\
\text { sion's Report (2004) provides } \\
\text { a serious, well-researched indictment } \\
\text { of the existing arrangements. } \\
\text { The separation project (2005-7) } \\
\text { unfolds internally, preparing the } \\
\text { administrative and political separation } \\
\text { of executive and legislative branches. } \\
\text { UK Government passes Government } \\
\text { of Wales Act 2006, which terminates } \\
\text { the Assembly's corporate body status. }\end{array}$ \\
\hline
\end{tabular}

The interim constitution (2007-2011) Government of Wales Act 2006
Primary powers conferred powers model (2011-2016) Government of Wales Act 2006 (Part IV) Wales Act 2014
Labour wins only 26 of the 60 Assembly seats in May 2007 but the possibility of a 'rainbow coalition' (Plaid, Lib Dems, Conservatives) fails to materialise.

Labour and Plaid enter coalition under the 'One Wales' agreement, which was ratified by both parties in their respective conferences in autumn 2007.

In 2007, Mike German AM, the Welsh Lib Dems Assembly leader, succeeds Lembit Opik as Welsh Liberal Democrats' leader. In December 2008, Kirsty Williams is elected leader of the Welsh Lib Dems.

Rhodri Morgan steps down from the Welsh Labour party leadership, and Carwyn Jones AM wins the ensuing contest in December 2009 becoming the new First Minister of Wales.

Welsh Labour wins 30 of the 60 seats in the Assembly elections, and sets out to form a government alone. Plaid Cymru loses four seats and its official opposition status. leuan Wyn Jones steps down from party
The Holtham Commission is set up by the Welsh Government in 2008 to assess the merits of the current system of financing devolution (Barnett formula) and identify possible alternatives, including tax varying powers and greater borrowing powers for the Welsh Government. The commission argued for a needs-based approach to financing devolution.

An all-Wales Convention is set up in 2008 with a remit to educate the Welsh public about the current devolution settlement and advise on proceeding with a referendum on moving to primary law-making power (as per Government of Wales Act 2006, Part IV). The Commission recommends that a referendum on this issue should be held before June 2010 . The vote eventually takes place in March 2011, resulting in approval of the new powers by 63.49 per cent to 36.51 per cent, on a turnout of just 32.5 per cent.

The Commission on Devolution in Wales (Silk Commission) is established by the UK Government in 2011 to revisit 1 ) the financial powers and arrangements of devolution in Wales and 2) the Assembly's powers. 
Table 19.1 (Cont.)

\begin{tabular}{|c|c|c|}
\hline Interregnums & Political developments & Constitutional developments \\
\hline $\begin{array}{l}\text { Primary powers - } \\
\text { reserved powers } \\
\text { model ( } 2017 \\
\text { onwards) } \\
\text { W ales Act } 2017\end{array}$ & $\begin{array}{l}\text { Inconclusive Assembly elections. Gov- } \\
\text { ernment formation takes an unusual } \\
\text { turn with the nomination of Plaid } \\
\text { Cymru's Leanne Wood as First Minis- } \\
\text { ter, who also support from Conserva- } \\
\text { tives, and UKIP, making the contest } \\
\text { a tight one, with } 29 \text { to } 29 \text { votes for } \\
\text { each Carwyn Jones and Leanne Wood. } \\
\text { The following week, Plaid decided to } \\
\text { withdraw, Wood's nominations, ensur- } \\
\text { ing Carwyn Jones' investiture for a fifth } \\
\text { Labour government in Cardiff since } \\
\text { 1999. Negotiations between Plaid and } \\
\text { Labour ensure government support on } \\
\text { a compact basis, but this ends in } 201 . \\
\text { UKIP makes an electoral breakthrough, } \\
\text { with } 7 \text { seats won, but leadership } \\
\text { squabbles and the emergence of } \\
\text { a Brexit Party wing characterise their } \\
\text { first term. } \\
\text { Carwyn Jones steps down as FM and } \\
\text { Welsh Labour leader in April } 2018 \text {. The } \\
\text { leadership contest is won by Mark Dra- } \\
\text { keform AM, who becomes First Minis- } \\
\text { ter of Wales in December } 2018 \text {. } \\
\text { In September } 2018, \text { Adam Price AM } \\
\text { becomes the Leader of Plaid Cymru } \\
\text { and Paul Davies AM becomes leader of } \\
\text { the Welsh Conservative party. }\end{array}$ & 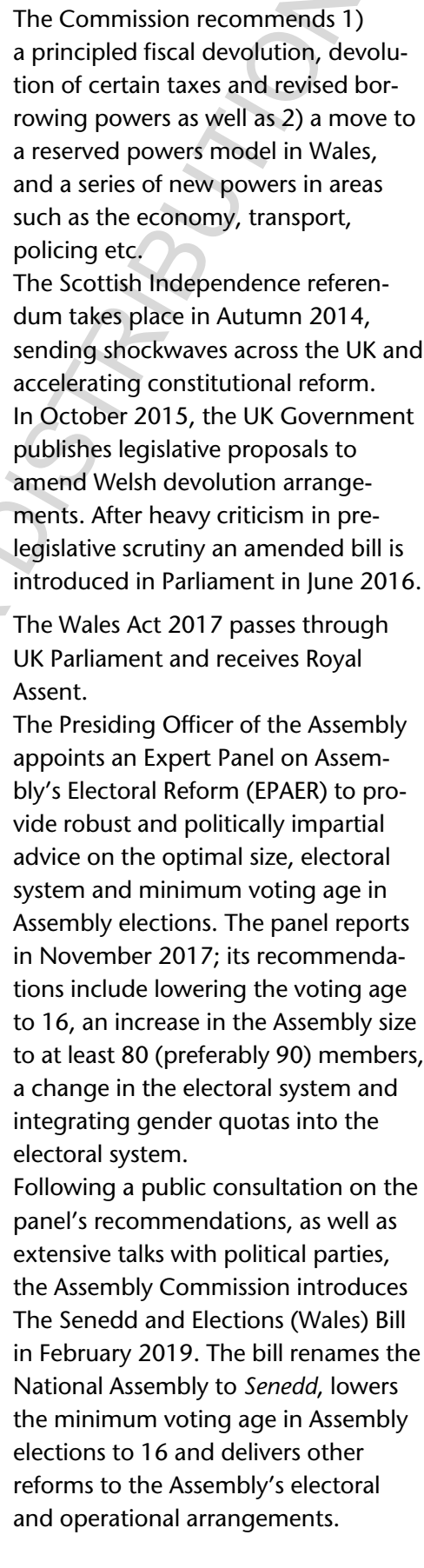 \\
\hline
\end{tabular}




\section{Diana Stirbu and Laura McAllister}

Welsh Labour has seen most significant change and certainly more autonomy in terms of policy creation post-devolution (Denton \& Deacon, 2018). Rhodri Morgan, the First Minister between 2000 and 2009, talked of establishing 'clear red water' between Cardiff and the then Blair government in London. Some significant policy differentiation has indeed happened around free NHS prescriptions, tuition fees in higher education, and more recently, presumed consent for organ donations and proposals to ban the smacking of children. It has been argued that a long, uninterrupted stint in government may have prevented more radical policy thinking from Labour. Welsh Labour has more autonomy in terms of internal structures, rules, organisation and candidate selection, the latter being firmly in the hands of local branches. The Welsh Labour party leadership contest of 2018 was the first under the new rules of 'one member, one vote' (OMOV), replacing the more traditional electoral-college process. Mark Drakeford, a Jeremy Corbyn supporter, won the contest in the second ballot with 53.9 per cent of the votes, defeating fellow AMs, Vaughan Gething and Eluned Morgan.

The degree of Welsh Conservatives' ideological adaptation to devolution is perhaps the most significant (and remarkable) of all the parties. The party had been firmly antidevolutionist in 1997 and before, but some talented and Welsh-identifying leaders, especially Nick Bourne between 1999 and 2011, recognised the opportunities if the party was to adapt and develop a more distinctive Welsh identity for itself. Correlated to some visible improvements in vote-share, both in local and Westminster elections, the Welsh Conservatives settled pragmatically in the opposition role (being the main opposition party in the third and fifth Assembly terms). The Conservatives have held several leadership positions in the Assembly, chairing influential committees like the Finance Committee (Angela Burns, 2008-11), as well as filling the position of Deputy Presiding Officer between 2011 and 2016 (David Melding AM). Whilst not actively advocating further powers, the party has contributed to debates on greater devolution, notably through the Richard Commission and the Silk Commission. It was also sufficiently independent to criticise the UK Government's attempts to limit Assembly's powers or to frustrate intergovernmental arrangements.

After a superb start, where it performed better than its nationalist counterpart in Scotland, the SNP, winning 17 seats, Plaid Cymru has struggled somewhat in the new devolved context. A combination of ineffective leadership under Ieuan Wyn Jones (Denton \& Deacon, 2018), and poor positioning in respect of Welsh Labour moving on to a soft nationalist agenda under both Rhodri Morgan in 2007 and then Carwyn Jones from 2010, meant that that party's progress has been relatively stagnant. Significant for the party was its spell in government under the One Wales coalition agreement with Labour between 2007 and 2011. This effectively gave Plaid three full ministers and one junior minister in the Welsh Cabinet. Whilst the party membership supported the idea of power-sharing, some argued that Plaid's participation in government as a junior coalition partner undermined the goal of changing 'historically embedded stereotypes' with regards to stateless nationalist regional parties (McAngus, 2016, 634). Coalition government participation did not translate into electoral benefits for Plaid, as they lost four seats in the 2011 elections and their status as official opposition. Under Leanne Woods' leadership (from 2012 until 2018), the party's profile and visibility increased across the UK, but this did not result in significant electoral gains. Adam Price, Woods' successor in 2018 , set out to clarify the party's position on key issues, such as independence and remaining part of the EU, aiming to offer a credible alternative to Labour.

The Welsh Liberal Democrats performed well enough in the first Assembly elections, with six AMs making them obvious coalition partners for Labour in 2000. When the party 
had an opportunity to form an alternative 'rainbow' coalition led by Plaid in 2007 that would also have included the Conservatives, the party voted against. From 2011, the party suffered a catastrophic loss in popularity in Wales (in keeping with its general malaise after joining the Conservative-led coalition at Westminster), and, in the 2016 elections, the party won just one seat. However, given the electoral arithmetic in the fifth Assembly and acrimonious relations between Plaid and Labour, the party was again the 'go-to' coalition partner for the fifth Labour-led government since 1999. The crisis of popularity that affected the Liberal Democrats after 2010 seems to have been somewhat reversed in the UK as a whole since the 'Brexit' referendum, but in Wales the party continued to languish in opinion polls.

UKIP made its breakthrough in Welsh politics in 2016 by riding the eurosceptic wave, although it had begun to make electoral inroads in Wales from the 2009 European elections (Denton \& Deacon, 2018). With a rather haphazard organisation and structure, UKIP in Wales is a regional branch of the UK party and devolution would appear to have made little impact on its structure or approach (although it certainly gave its original seven AMs profile and status). The single focus of the party's agenda (exiting the European Union) has meant limited thinking on broader policy areas or on the development of devolution. Thus, its presence in Wales remained insignificant until 2014. Whilst its 2016 electoral performance seemed to put the party firmly on the Welsh political map, the 2017 general election and Welsh local elections told a different story. Party support slumped to a derisory 1.1 per cent vote share in the local elections. Internal squabbling and the continued popularity of the former leader Nigel Farage ultimately saw the party fracture in Wales, with four UKIP AMs defecting to the Brexit Party in May 2019.

The Brexit Party won a remarkable 32.46 per cent of the vote in Wales in the 2019 European parliamentary election. However, in the Brecon and Radnorshire Westminster byelection of August 2019, the party's vote share plummeted to just 10.47 per cent.

\section{Electoral systems and representation}

There are three electoral systems currently in use in Wales. Each system has advantages and disadvantages in terms of clarity, intelligibility to voters, representativeness and potential to invigorate democracy. Matters relating to the electoral system and franchise for local and Assembly elections have only been devolved since the 2017 Wales Act, which came into force in April 2018.

\section{Electoral systems}

For local government and Westminster elections, the First Past the Post (FPTP) or 'simple plurality' system is used. FPTP is a straightforward, easily understood system that, arguably, strengthens the relationship between voters and a single elected representative in the constituency (see Chapter 6 above). However, not even its staunchest advocate could argue that it provides a reliable reflection of public opinion, and its weakness in this respect has led to increasing criticism in recent years. Members of the Assembly are elected through the Additional Member System (AMS), a hybrid voting system that combines FPTP with list-based proportional representation (PR). Accordingly, 40 members are elected from single member constituencies and a further 20 Assembly Members emerge from a party list competition based on five regions corresponding to the boundaries for European parliamentary elections. The Welsh version of AMS has been criticised for its limited proportionality (Stirbu \& McAllister, 2016). 
Diana Stirbu and Laura McAllister

\section{Turnout in elections}

Turnout in elections held in Wales is still highest for the General Election for the UK Parliament, with post devolution turnout figures ranging from 61.6 per cent in 2001 to 68.6 per cent in 2017. This reflects similar trends to the UK average turnout in recent general elections (lowest turnout of 59.4 per cent in 2001, highest at 68.8 per cent in 2017). Turnout in Assembly elections has been significantly lower. The highest turnout was in the first election in 1999 (46 per cent), its lowest in the second election in 2003 (38.2 per cent) (HoC Library, 2019). Turnout in local elections has declined slightly since devolution, whilst the figures for European parliamentary elections have been consistently low both in Wales and the UK.

\section{Electoral history}

In terms of party success, with the exception of two European elections (2009 and 2019), Labour has 'won' every parliamentary election in Wales since 1918. Such is its dominance at national level that Labour has been in government for all 20 years of devolution - either as a majority government, or in coalition or a minority government sustained by deals with other parties. At local government level, since devolution, Welsh Labour has enjoyed the largest voteshare for a political party (leaving aside significant, but geographically patchy, support for independents). This ranged from 34.4 per cent in 1999 , to a low of 25.6 per cent in 2008 , a high of 35.6 per cent in 2012 and 30.5 per cent in 2017. In terms of seats share in the last local elections in Wales, despite significant losses (107 seats) the Welsh Labour still topped the list with 38 per cent, whilst Plaid Cymru and the Welsh Conservatives claimed only 16 and 15 per cent of the seats (HoC Library, 2017).

However, despite its evident electoral success, Labour has seen dramatic swings in vote share both in Assembly elections (see Table 19.2) and in general elections (dropping from 54.7 per cent in the 1997 general election to 36.2 per cent in 2010. Additionally, the results in the 2019 European elections, when the Brexit Party topped the poll in 19 of the 22 council areas in Wales, also raises concerns over Welsh Labour's relationship with its traditional supporters.

There has been a gradual collapse in the Welsh Liberal Democrats' regional vote share (from 14.8 per cent in 2007 to 2.9 per cent in 2016), from which the party had previously secured most of its Assembly representation (see Table 19.2). This trend is also reflected in local and UK parliamentary elections (see Figure 19.1).

Table 19.2 National Assembly elections vote share in constituency and regional vote (1999-2016)

\begin{tabular}{|c|c|c|c|c|c|c|c|c|c|c|}
\hline \multirow{2}{*}{$\begin{array}{l}\text { National Assem- } \\
\text { bly elections }\end{array}$} & \multicolumn{2}{|c|}{$\begin{array}{c}1999 \\
\text { Const/Regional }\end{array}$} & \multicolumn{2}{|c|}{$\begin{array}{c}1999 \\
\text { Const/Regional }\end{array}$} & \multicolumn{2}{|c|}{$\begin{array}{c}1999 \\
\text { Const/Regional }\end{array}$} & \multicolumn{2}{|c|}{$\begin{array}{c}1999 \\
\text { Const/Regional }\end{array}$} & \multicolumn{2}{|c|}{$\begin{array}{c}1999 \\
\text { Const/Regional }\end{array}$} \\
\hline & 37.6 & 35.4 & 40 & 36.6 & 32.2 & 29.6 & 42.3 & 35.9 & 34.7 & 31.5 \\
\hline $\begin{array}{l}\text { Welsh } \\
\text { Conservatives }\end{array}$ & 15.8 & 15.8 & 19.9 & 19.2 & 22.4 & 21.4 & 25 & 22.5 & 21.1 & 18.8 \\
\hline $\begin{array}{l}\text { Welsh Liberal } \\
\text { Democrats }\end{array}$ & 13.5 & 13.5 & 14.1 & 12.7 & 14.8 & 11.7 & 10.6 & 8 & 7.7 & 2.9 \\
\hline Plaid Cymru & 28.4 & 28.4 & 21.2 & 19.7 & 22.4 & 21 & 19.3 & 19.9 & 20.5 & 20.8 \\
\hline UKIP & - & - & - & - & - & - & - & - & 12.5 & 13 \\
\hline
\end{tabular}




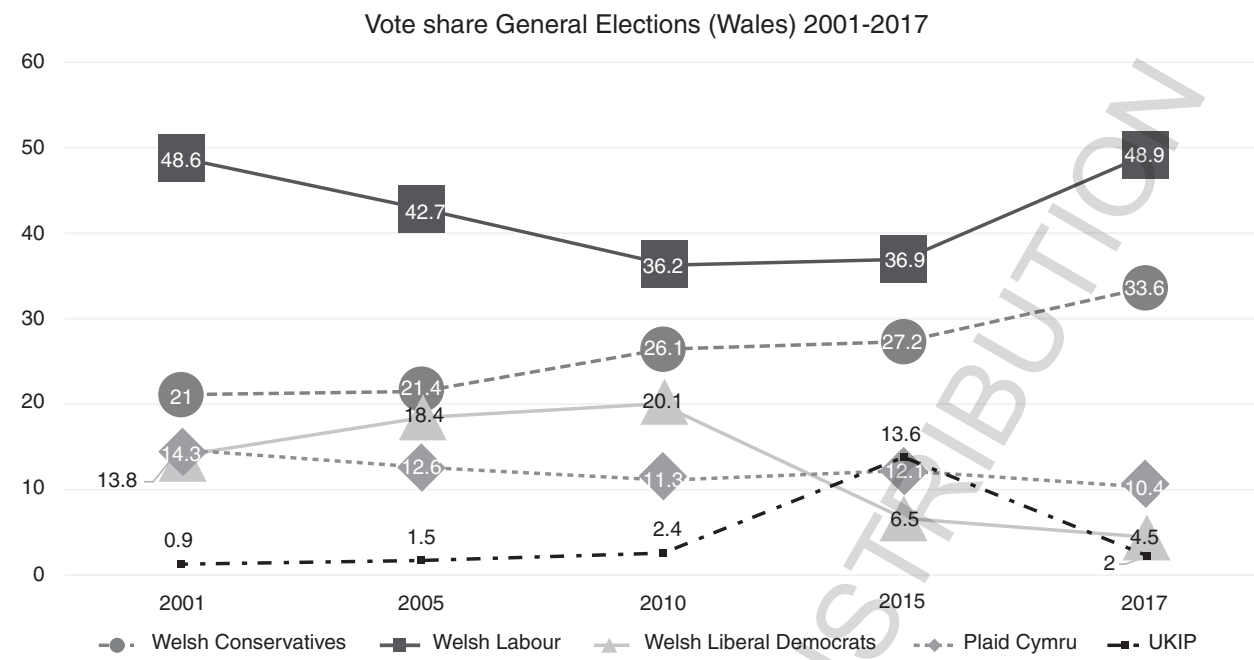

Figure 19.1 Vote share in General elections Wales (2001-2017)

Other significant developments saw a steady increase in vote share for the Welsh Conservatives, who achieved an all-time high of 33.6 per cent in the 2017 contest in general elections (see Figure 19.1) and 18.8 per cent in local elections in the same year (HoC Library, 2017).

\section{Gender representation}

One of devolution's greatest achievements is the progress in gender representation in the Assembly, which has seen the highest percentage of women elected of all the UK's national legislatures. At the 2016 Assembly elections, 41.7 per cent of the successful candidates were women (Stirbu et al., 2018). More remarkably, the percentage of women in the Assembly has never dropped under 40 per cent since its establishment. These results came in the wake of positive action taken around candidate selection by two political parties: Labour and Plaid Cymru (McAllister \& Stirbu, 2007a). These breakthroughs, however notable, are not guaranteed to continue in the absence of supportive legislative and political measures according to the Expert Panel on Assembly Electoral Reform (2017), especially as they have not permeated other levels of electoral politics in Wales. To illustrate this, despite Labour's dominance in Wales and its pioneering positive action initiatives (twinning and all-women shortlists) the percentage of women elected in UK parliamentary elections in Welsh constituencies has consistently been lower than the corresponding figure for the UK as a whole (i.e. the proportion of women in the House of Commons after the 2017 elections was 32 per cent, whilst the figure for Welsh seats was only 27.5 per cent) (Stirbu et al., 2018). Similar patterns are evident in local elections in Wales, where the percentage of women elected as local councillors is higher than in Northern Ireland but less than in Scotland or England (Stirbu et al., 2016).

The Expert Panel on Assembly Electoral Reform, which reported in 2017, recommended that gender quotas should be enshrined in a reformed and more proportional electoral system. The Assembly Commission has adopted a staged approach to implementing the panel's recommendations, starting with the less controversial issue of lowering the voting age to 16 for Assembly elections. 


\section{Developments in scholarship}

Within UK political science scholarship, Welsh and Wales-specific political analysis was relatively underdeveloped prior to devolution. A focus on history, language, class, identity, nationhood and nationalism dominated scholarship. A significant element of scholarly analysis attempted to explain perceived Welsh 'exceptionalism' and political deviation from the British norm (Balsom et al., 1984). This relied on theoretical constructions around language and identity, as well as on the organisation of social structures in Wales. Post-devolution, the pace and scope of change within Welsh political and constitutional arrangements have provided more fertile ground for scholarly inquiry across multiple dimensions of politics, ranging beyond the constructs of identity and social structure.

Since devolution, understandings of Welsh identity have developed, both in scope and methods. Whilst language and territory remain important determinants, more sophisticated methods of inquiry, including longitudinal and comparative approaches, have been applied to test some of the assumptions of the pre-devolution literature, such as Balsom's 'Three Wales Model' (1985) (see Scully \& Wyn Jones, 2012), and to broaden the theoretical base underpinning interpretations of national identity. For example, longitudinal studies on public attitudes, voting behaviour and political engagement provided a significant evidence base with regards to the entrenchment of devolution in Wales (Wyn Jones \& Scully, 2006; YouGov/Welsh Barometer polling ${ }^{3}$ ), or the development at different paces of the notions of 'Welshness', 'Scottishness' (Scully, 2013) and 'Englishness' (Henderson et al., 2016).

Scholarship also focuses more on transformations at the level of political parties as a result of devolution; some of these transformations are anchored in 'Welsh identity' discourses (Andrews \& Bradbury, 2010), as well as in rational choice (Laffin \& Shaw, 2007; Lynch, 2004; McAllister, 2001) and political pragmatism narratives (Elias, 2012; Wall \& Williams, 2017). Elias (2009) states that most of these dilemmas are common to most small regional parties in their adaptation to different constitutional settings (such as devolution), one important dynamic being the ideological adaptation from 'party of protest' to 'party of power'. Important external and internal pressures (such as vote-seeking, policy-seeking and office-seeking) play into this ideological adaptation. The work of Wyn Jones (2009) and McAllister (2001) also focuses on the ideological adaptation of Plaid Cymru and suggests that the party's exposure to European institutions played a role in the abandonment of Plaid's commitment to the utopian post-sovereign Europe and embracing independence as a long-term goal. Awan-Scully (2018) focuses on the effect of devolution, maturing politics and changes in voting patterns in the UK's nations, questioning the nature and sustainability of a 'British' party politics.

Nationalism and nationhood have also preoccupied pre-devolution scholarly analysis. Beyond language and identity, other determinants, such as culture and territory (Gruffudd, 1995) attracted the attention of political scientists. But much pre-devolution scholarship lacked, a clear institutional focus; the elements of territory and regionalism were explored mostly through the perspective of locating Wales within the British context (Morgan, 1980), rather than articulating Welsh politics as a territorial manifestation of British politics.

Post devolution, there has been an interest in institution- and constitution-building as a proxy for nation-building. Institutionalist perspectives on the development of the National Assembly for Wales and on the changing constitutional landscape in which the new political institutions developed underpin this focus. Welsh exceptionalism, once again, dominates the narratives, which focus on the unusual constitutional arrangements, set-up and operation of the Assembly (see Rawlings, 2003; Rawlings,; McAllister, 1999; McAllister \& Stirbu, 2007b; 
Stirbu \& McAllister, 2018) and the dissonance between constitutional deliberation and the piecemeal and path-dependent approaches to political and constitutional change (McAllister, 2005). Additionally, the impact of the new politics on revitalising social capital within Wales (Chaney et al., 2001; Royles, 2006, 2007) as well as the impact of the new politics on the economy and public services (Andrews \& Martin, 2010; Jones et al., 2005) complement a body of significant scholarship.

The emergence of a Welsh legislative studies arena is a significant development in political science scholarship since 1999, the focus being placed on legislative institutionalisation (Bush, 2004; Rawlings, 2005; Watkin \& Greenberg, 2018), differentiation (Hunt, 2010) and on the development of a Welsh legal identity (Navarro, 2012; Stevenson, 2013; Wales Governance Centre, 2016; Pritchard, 2017, 2019). The Commission on Justice in Wales, set up by the Welsh Government in 2017 to review the operation of the justice system in Wales provided further impetus for scholarly inquiry at the intersection of political and legal studies in Wales.

More recent preoccupations in scholarship also include political representation, the impact of new democracy and new institutions. The field has experienced methodological diversification and sophistications, with comparative and longitudinal studies now complementing the existing institutionalist approaches. The body of scholarship around political representation in Wales has sought to describe and explain the significant progress achieved in terms of gender representation (Chaney, 2003), but also to contextualise these developments within the UK more widely (Chaney et al., 2007; Mackay \& McAllister, 2012; Russell et al., 2002). Stirbu et al. (2018) advance the analysis by reflecting on the changes in electoral opportunities for women as a result of devolution, as well as the lack of a 'contagion effect' across other levels of politics in Wales.

Electoral studies have also seen a deepening and extension of analysis. From electoral behaviour and voting intentions at various levels of elections (Awan Scully, 2013-19; Wyn Jones and Scully, 2006), to public attitudes towards constitutional matters and studies of electoral accountability in Wales (Cole, 2006; Dafydd \& Badanjak, 2018; Scully et al., 2004), this scholarship has been instrumental in enhancing understanding of the complexity and depth of a new democratic Welsh landscape.

\section{Conclusion}

At one level, the story of the 'new' Welsh politics since devolution maintains the continuity, but it is also a story with some significant departures. This chapter has outlined some of the major changes, especially the maturing and adjustment of Welsh political institutions to the new reality of multi-level politics and governance, the transformation of the political parties and how they operate, and how electoral politics has changed.

Overall, Wales stands out from the other devolved nations in terms of the pace and volume of constitutional change, and it has undergone this process set against a context of prolonged political continuity and the dominance of a single party: Welsh Labour. The National Assembly for Wales of 2019 barely resembles the institution established 20 years ago, the changing of its name to 'Senedd' is important but simply reflects its transformation. Political parties in Wales, bar UKIP and the Brexit Party, have all managed to adapt to devolution, both in terms of autonomy, branding and Welsh identity, as well as in terms of their strategic positioning for elections. Yet we have also highlighted instances where the political connection between Wales and England is as strong as ever, particularly in voting in the 2016 EU referendum. 


\section{Diana Stirbu and Laura McAllister}

Modern Welsh politics has been shaped by its new political institution established in 1999. Inevitably, devolved politics has provided a fertile ground for the development of a new autochthonous scholarship, as well as attracting the interest of scholars from outside Wales. Comparative and longitudinal methods have supported a radical new way of studying Welsh politics - not simply positioning Wales within the politics of the United Kingdom, but contextualising an emergent Welsh politics within the UK and beyond.

\section{Notes}

150.3 per cent voted 'yes' for the establishment of the Assembly in the 1997 Referendum, vs. 49.7per cent who voted 'no'.

2 The Senedd and Elections Bill introduced in February 2019, proposes the change in name from Assembly to Senedd (Parliament in Welsh).

3 For analysis of the Welsh Political Barometer see Cardiff University's Elections in Wales Blog: https://blogs.cardiff.ac.uk/electionsinwales/. For YouGov data: https;//yougov.co.uk/topics/over view/all(popup:search/welshpercent20barometer).

\section{References}

Andrews, R. \& Martin, S. (2010). Regional variations in public service outcomes: The impact of policy divergence in England, Scotland and Wales. Regional Studies, 44(8), 919-934.

Andrew, R. \& Bradbury, J. (2010). State devolution and national identity: Continuity and change in the politics of welshness and britishness in Wales. Parliamentary Affairs, 63(2), 229-249.

Awan Scully, R. (2013-19). Elections in Wales Blog, Cardiff University, URL: https://blogs.cardiff.ac.uk/ electionsinwales/

Awan-Scully, R. (2018). The end of British party politics? London: Biteback Publishing.

Balsom, D. (1985). The three-Wales model. The National Question Again, 1-17.

Balsom, D., Madgwick, P., \& Van Mechelen, D. (1984). The political consequences of Welsh identity. Ethnic and Racial Studies, 7(1), 160-181.

Bradbury, J. (2006). British political parties and devolution: Adapting to multi-level politics in Scotland and Wales. Devolution and Electoral Politics, 214-247.

Bradbury, J. \& Andrews, R. (2009). State devolution and national identity: Continuity and change in the politics of Welshness and Britishness in Wales. Parliamentary Affairs, 63(2), 229-249.

Bush, K. (2004). New approaches to UK Legislative drafting: The Welsh perspective. Statute Law Review, 25(2), 144-150.

Wales Governance Centre. (2016). Justice in Wales: Principles, progress and next steps. Cardiff: Cardiff University.

Chaney, P. (2003). Women and constitutional change in Wales. Belfast: Centre for Advancement of Women in Politics.

Chaney, P., Hall, T. A., \& Pithouse, A. J. (2001). New governance-new democracy? Post-devolution Wales. Cardiff: University of Wales Press.

Chaney, P., Mackay, F., \& McAllister, L. (2007). Women, politics and constitutional change: The first years of the national assembly for Wales. Cardiff: University of Wales Press.

Cole, M. (2006). Asymmetrical public accountability: The National Assembly for Wales, questions and Quangos. Political Quarterly, 77(1), 98-106.

Dafydd, E. \& Badanjak, S. (2018). Electoral accountability, responsibility attributions, and the democratic deficit in devolved Wales. Parliamentary Affairs.

Deacon, R. (2018) 'The evolution of Welsh devolution' in R. Deacon et al. (Ed.), The government and politics of Wales (pp. 1-21). Edinburgh: University Press.

Denton, A. \& Deacon, R. (2018). 'Welsh politics, ideology and political parties' in Russell Deacon, et al. (Ed.), The government and politics of wales (pp. 22-44). Edinburgh: University Press.

Elias, A. (2009). Plaid Cymru and the challenges of adapting to post-devolution Wales. Contemporary Wales, 22(1), 113-140. 
Elias, A. (2012, September). Policy-making capacity of political parties in Wales. In United Kingdom: A Changing Union Conference.

Gruffudd, P. (1995). Remaking Wales: Nation-building and the geographical imagination, 1925-1950. Political Geography, 14(3), 219-239.

Henderson, A., Jeffery, C., Liñeira, R., Scully, R., Wincott, D. \& Wyn Jones, R. (2016). England, Englishness and Brexit. The Political Quarterly, 87(2), 187-199.

HoC Library. (2017). Local elections 2017, Briefing no. 7975. London: HoC.

HoC Library. (2019). Turnout at elections, Briefing no. CBP 8060. London: HoC.

Hunt, J. (2010). Devolution and differentiation: Regional variation in EU law. Legal Studies, 30(3), 421-441.

Jones, R., Goodwin, M., Jones, M. \& Pett, K. (2005). Filling in the state: Economic governance and the evolution of devolution in Wales. Environment and Planning C: Government and Policy, 23(3), 337-360.

Laffin, M. \& Shaw, E. (2007). British devolution and the labour party: How a national party adapts to devolution. The British Journal of Politics and International Relations, 9(1), 55-72.

Lynch, P. (2004). Saving the union: Conservatives and the 'Celtic Fringe'. The Political Quarterly, 75(4), 386-391.

Mackay, F. \& McAllister, L. (2012). Feminising British politics: Six lessons from devolution in Scotland and Wales. The Political Quarterly, 83(4), 730-734.

McAllister, L. (1999). The road to Cardiff Bay: The process of establishing the National Assembly for Wales. Parliamentary Affairs, 52(4), 634-648.

McAllister, L. (2000). The new politics in Wales: Rhetoric or reality? Parliamentary Affairs, 53(3), 591-604.

McAllister, L. (2001). The National Assembly election: Plaid Cymru's coming of age. Contemporary Wales, 14, 109-114.

McAllister, L. (2005). 8. The Richard Commission-Wales's alternative constitutional convention? Contemporary Wales, 17(1), 128-139.

McAllister, L. \& Stirbu, D. S. (2007a). Opportunities for gender innovations in a new political space. International Journal of the Interdisciplinary Social Sciences, 1(1), 1-11.

McAllister, L. \& Stirbu, D. (2007b). Developing devolution's scrutiny potential: A comparative evaluation of the National Assembly for Wales's Subject Committees. Policy \& Politics, 35(2), 289-309.

McAngus, C. (2016). Party elites and the search for credibility: Plaid Cymru and the SNP as new parties of government. The British Journal of Politics and International Relations, 18(3), 634-649.

Morgan, K. O. (1980). Wales in British politics, 1868-1922. Cardiff: University of Wales Press.

Navarro, M. (2012). A substantial body of different Welsh law: A consideration of Welsh subordinate legislation. Statute law review, 33(2), 163-191.

Pritchard, H. (2017). 'Building a Welsh jurisdiction through administrative justice' in S. Nason (Ed.), Administrative Justice in Wales and comparative perspectives (pp. 218-242). Cardiff: Public Law in Wales, University of Wales Press.

Pritchard, H. (2019). Revisiting legal Wales. Edinburgh Law Review, 23(1), 123-130.

Rawlings, R. (1998). The new model Wales. Journal of Law and Society, 25(4), 461-509.

Rawlings, R. (2003). Delineating Wales: Constitutional, legal and administrative aspects of national devolution (pp. 1-644). Cardiff: University of Wales Press.

Rawlings, R. (2005). 'Law making in a virtual parliament: The Welsh experience' in R. Hazell \& R. Rawlings (Eds.), Devolution, law making and the constitution (pp. 71-111). Exeter: Imprint.

Rawlings, R. W. (2018). The strange reconstitution of Wales. Public Law, 2018, 62, 62-83.

Royles, E. (2006). Civil society and the new democracy in post-devolution wales-A case study of the EU structural funds. Regional \& Federal Studies, 16(2), 137-156.

Royles, E. (2007). Revitalising democracy? Devolution and civil society in Wales. Cardiff: Gwasg Prifysgol Cymru| University of Wales Press.

Russell, M., Mackay, F., \& McAllister, L. (2002). Women's representation in the Scottish Parliament and National Assembly for Wales: Party dynamics for achieving critical mass. Journal of Legislative Studies, 8 (2), 49-76.

Scully, R. (2013). More Scottish than Welsh? Understanding the 2011 devolved elections in Scotland and Wales. Regional \& Federal Studies, 23(5), 591-612.

Scully, R. \& Wyn Jones, R. (2012). Still three Wales? Social location and electoral behaviour in contemporary Wales. Electoral Studies, 31(4), 656-667. 


\section{Diana Stirbu and Laura McAllister}

Scully, R., Wyn Jones, R. \& Trystan, D. (2004). Turnout, participation and legitimacy in post-devolution Wales. British Journal of Political Science, 34(3), 519-537.

Stevenson, L. (2013). An emerging Welsh legal identity: A brief overview of the information landscape. Legal Information Management, 13(3), 156-161.

Stirbu, D. (2010). The invisible constitution: The impact of devolution on UK constitutional dynamics-institutional developments in Wales, Doctoral dissertation, University of Liverpool.

Stirbu, D., Larner, J. \& McAllister, L. (2016) 'Pitiful progress: Women councillors in Wales after the 2017 local elections', Athena Talks, Medium, URL: https://medium.com/athena-talks/pitiful-progresswomen-councillors-in-wales-after-the-2017-local-elections-edbf39258c7

Stirbu, D., Larner, J., \& McAllister, L. (2018). 'Gender representation in Wales: New approaches to candidate selection in UK's devolved legislatures and beyond' in G. Cordero, and X. Coller (Eds.), Democratizing candidate selection (pp. 201-230). Cham: Palgrave Macmillan.

Stirbu, D. S. \& McAllister, L. (2016). If it's broken, fix it! Time to rethink the AMS electoral system in Wales. Democratic Audit UK.

Stirbu, D. S. \& McAllister, L. (2018). Chronicling National Assembly committees as markers of institutional change. The Journal of Legislative Studies, 24(3), 373-393.

Wall, M. \& Williams, S. (2017). Seeking evidence for a Welsh progressive consensus: Party positioning in the 2016 National Assembly for Wales election. Parliamentary Affairs, 71(4), 820-844.

Watkin, T. G. \& Greenberg, D. (2018). Legislating for Wales. Cardiff: University of Wales Press.

Wilson, D. J. (1994). Facing up to the 'democratic deficit'. Local Government Studies, 2, 193-201.

Wyn Jones, R. (2001). On process, events and unintended consequences: National identity and the politics of Welsh devolution. Scottish Affairs, 37(1), 34-57.

Wyn Jones, R. (2009). From Utopia to reality: Plaid Cymru and Europe. Nations and Nationalism, 15(1), 129-147.

Wyn Jones, R. \& Scully, R. (2006). Devolution and electoral politics in Scotland and Wales. Publius: The Journal of Federalism, 36(1), 115-134. 